\title{
COMPARISON OF DIMENSIONAL CHANGES IN LHTGR GRAPHITES BY IRRADIATION IN THE HFIR (CAPSULES HT-20, HT-21, HT-22, AND HT-23)
}

W. R. JOHNSON

Prepared under

Contract E(04-3)-167

Project Agreement No. 17

for the San Francisco Operations Office

U.S. Energy Research and Development Administration 


\section{DISCLAIMER}

This report was prepared as an account of work sponsored by an agency of the United States Government. Neither the United States Government nor any agency Thereof, nor any of their employees, makes any warranty, express or implied, or assumes any legal liability or responsibility for the accuracy, completeness, or usefulness of any information, apparatus, product, or process disclosed, or represents that its use would not infringe privately owned rights. Reference herein to any specific commercial product, process, or service by trade name, trademark, manufacturer, or otherwise does not necessarily constitute or imply its endorsement, recommendation, or favoring by the United States Government or any agency thereof. The views and opinions of authors expressed herein do not necessarily state or reflect those of the United States Government or any agency thereof. 


\section{DISCLAIMER}

Portions of this document may be illegible in electronic image products. Images are produced from the best available original document. 
:

4 
CONTENTS

1. SUMMARY . . . . . . . . . . . . . . . . . . . 1

2. INTRODUCTION . . . . . . . . . . . . . . . . . . 3

3. DESCRIPTION OF EXPERIMENTS . . . . . . . . . . . . . . . 4

3.1. Capsule Design .................... 4

3.2. Description of Test Specimens.............. 4

3.3. Preirradiation Dimensional Measurements . . . . . . . 7

4. CAPSUlE OPERATION AND EVALUATION . . . . . . . . . . . . 9

4.1. Capsule Operation . . . . . . . . . . . . . . . . 9

4.2. Irradiation Conditions . . . . . . . . . . . . . 9 9

5. POSTIRRADIATION EXAMINATION RESULTS . . . . . . . . . . . 13

5.1. Capsule Disassembly and Specimen Removal . . . . . . . 13

5.2. Specimen Dimensiona1 Measurements . . . . . . . . 13

6. CONCLUSIONS . . . . . . . . . . . . . . . . . 22

ACKNOWLEDGMENTS . . . . . . . . . . . . . . . . . . 23

REFERENCES . . . . . . . . . . . . . . . . . . . 24

APPENDIX: FABRICATION OF GRAPHITE "X"

FIGURES

1. Summary curves for comparison of dimensional changes of graphites irradiated in capsules HT-20 through HT-23 at 1214

to $1238 \mathrm{~K}$. . . . . . . . . . . . . . . . . . 2

2. Schematic of capsules HT-20 through HT-23 . . . . . . . . . 5

3. Dimensional changes of H-327 graphite as a function of fast neutron fluence at an irradiation temperature of 1214 to $1238 \mathrm{~K}$. . . . . . . . . . . . . . . 16

4. Dimensional changes of $\mathrm{H}-451$ graphite as a function of fast neutron fluence at an irradiation temperature of 1214 to $1238 \mathrm{~K}$. . . . . . . . . . . . . . . . . . . 1 


\section{FIGURES (Continued)}

5. Dimensiona1 changes of TS -1240 graphite as a function of fast neutron fluence at an irradiation temperature of 1214 to $1238 \mathrm{~K}$. . . . . . . . . . . . . . . . . 18

6. Dimensional changes of $\mathrm{H}-451 \mathrm{~L}$ graphite as a function of fast neutron fluence at an irradiation temperature of 1214 to $1238 \mathrm{~K} \cdot$. . . . . . . . . . . . . . . . . . . . . . 19

7. Axial dimensional change of graphite " $X$ " as a function of fast neutron fluence at an irradiation temperature of 1214 to $1238 \mathrm{~K}$.................. 20

TABLES

1. Graphites irradiated in capsules HT-20, HT-21, HT-22, and HT-23... . . . . . . . . . . . . . . . . 6

2. Loading pattern for graphite samples in irradiation capsules $\mathrm{HT}-20$, HT-21, $\mathrm{HT}-22$, and $\mathrm{HT}-23$. . . . . . . . . . . . . 8

3. Reactor power history for capsules HT-20 through HT-23 . . . . 10

4. Calculated fast fluences for capsules HT-20 through HT-23 . . . 11

5. Dimensional changes of graphites irradiated in capsules HT-20, HT-21, HT-22, and HT-23............... 15 


\section{SUMMARY}

HTGR fuel element block candidate graphites $\mathrm{H}-327, \mathrm{H}-451$, and TS-1240 and two experimental laboratory-prepared graphites, H451L and "X," were irradiated isothermally at about $1226 \mathrm{~K}$ in the High F1ux Isotope Reactor (HFIR) to HTGR end-of-life fluences of approximately $8 \times 10^{25} \mathrm{n} / \mathrm{m}^{2}$ (E > $29 \mathrm{fJ})_{H T G R}$ to compare dimensional changes. Graphite " $X$ " was prepared from the calcined petroleum coke used in candidate graphite S0818, which was not available in time for the experiment.

The dimensional change curves are summarized for comparison in Fig. 1 . Graphite TS-1240 contracted less than H-451 in both directions. TS -1240 exhibited no dimensional change in the radial direction, whereas $\mathrm{H}-451$ contracted a maximum of approximately $0.75 \%$ and then commenced to expand but showed no net expansion at $8 \times 10^{25} \mathrm{n} / \mathrm{m}^{2}$. Graphite $\mathrm{H}-451$ and graphite " $\mathrm{X}$ " showed similar contraction curves in the axial direction and contracted about twice as much as TS-1240. At the higher fluences in capsules HT-21 and HT-22, interference was observed between graphite H-451L specimens and their spines. Graphite H-451L contracted about $50 \%$ more than $\mathrm{H}-451$ at $3 \times 10^{25} \mathrm{n} / \mathrm{m}^{2}$. Graphite $\mathrm{H}-327$, an extruded needle-coke graphite, showed, as expected, the highest degree of anisotropy in its dimensional changes. 


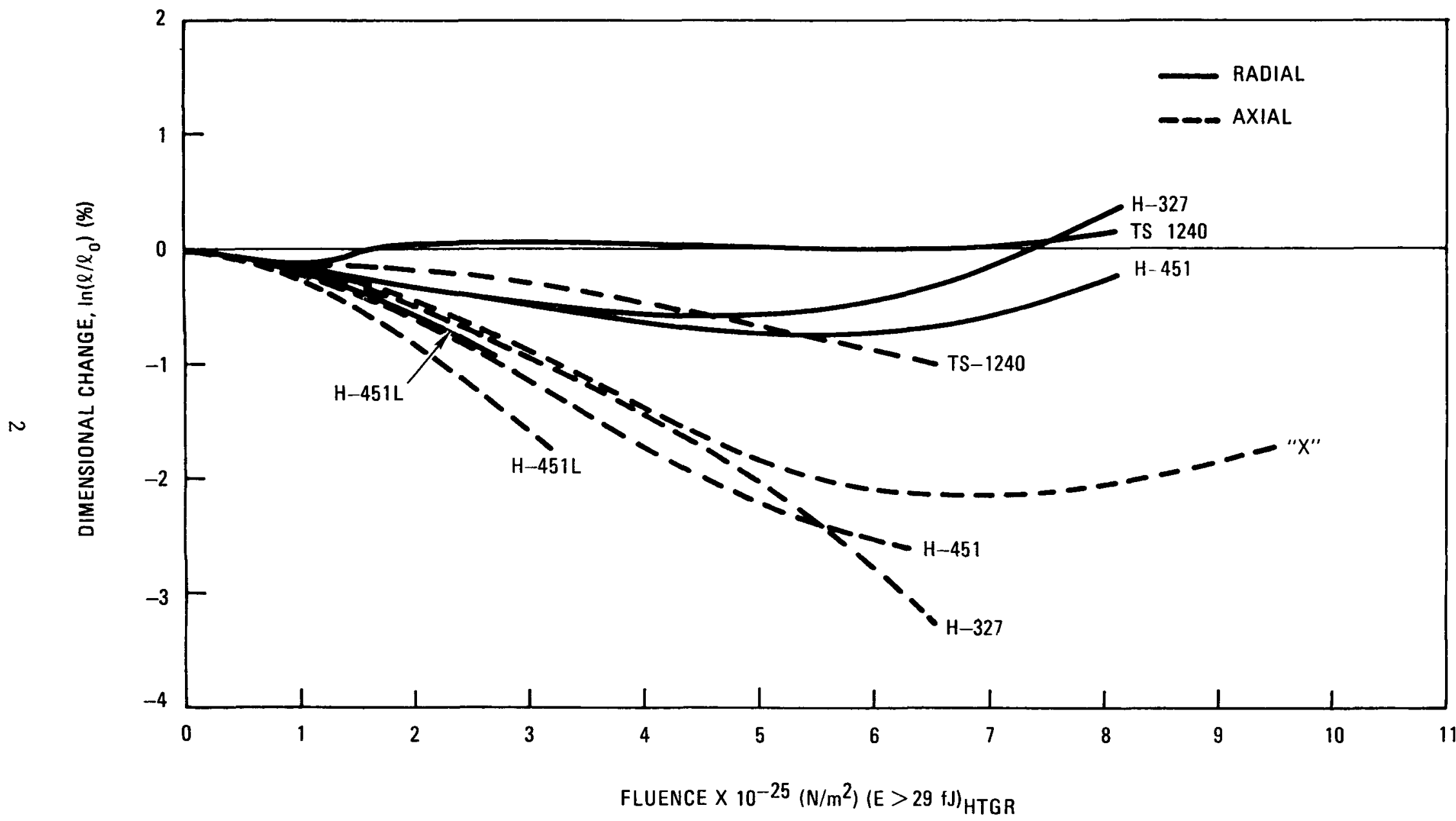

Fig. 1. Sumnary curves for comparison of dimensional changes of graphites irradiated in capsules HT-20 through HT-23 at 1214 to $1238 \mathrm{~K}$ 


\section{INTRODUCTION}

This report describes the results of dimensional measurements on graphite samples irradiated in capsules HT-20, HT-21, HT-22, and HT-23. Five graphites, including several candidate fuel element graphites for large high-temperature gas-cooled reactors (LHRGRs), were irradiated in the HFIR at the Oak Ridge National Laboratory (ORNL). The experiment was uninstrumented and uncontrolled and was designed to provide an accelerated test to enable a direct comparison of the dimensional changes of the graphites under similar irradiation conditions at fluences comparable to those near the end of LHTGR service 1ife. The data are incomplete and should not be used for purposes such as design calculations. Data in Ref. 1 should be consulted for design purposes. 


\section{DESCRIPTION OF EXPERIMENTS}

\subsection{CAPSULE DESIGN}

A sketch of capsules HT-20 through HT-23 is shown in Fig. 2. The outer containment vessel consisted of a water-cooled aluminum tube, $16.61 \mathrm{~mm}$ outside diameter by $13.46 \mathrm{~mm}$ inside diameter with a $482-\mathrm{mm}-1$ ong test specimen cavity. The graphite test specimens were contained within the aluminum tube near the ends of each capsule and were separated in groups of two or three by sandwich spacers composited from graphite foil, graphite, and zirconium foil. The zirconium foil was used as an oxygen "getter." The specimens were positioned within the aluminum containment tube by a series of connected 30.5-mm-diameter graphite spines (spools), which passed through the centers of the specimens and spacers and were secured at each end of the capsule. The specimens were centered within the aluminum tube by the graphite spines and by small nickel pins (standouts) located around the periphery of each graphite spacer. Heating of the test specimens was obtained by gamma-ray attenuation in tungsten wires located within hollow sections of the graphite spines. The atmosphere for each capsule was helium.

\subsection{DESCRIPTION OF TEST SPECIMENS}

Five graphites were irradiated in each capsule. A description of these graphites is given in Table 1.

Graphite H-327, an anisotropic needle-coke graphite produced by the Great Lakes Carbon Corporation (GLCC), is the fuel element graphite currently in the Fort St. Vrain (FSV) HTGR. Graphites H-451 and TS-1240, manufactured by GLCC and Union Carbide Corporation (UCC), respectively, are full-size, preproduction near-isotropic materials that are candidates for fuel element 

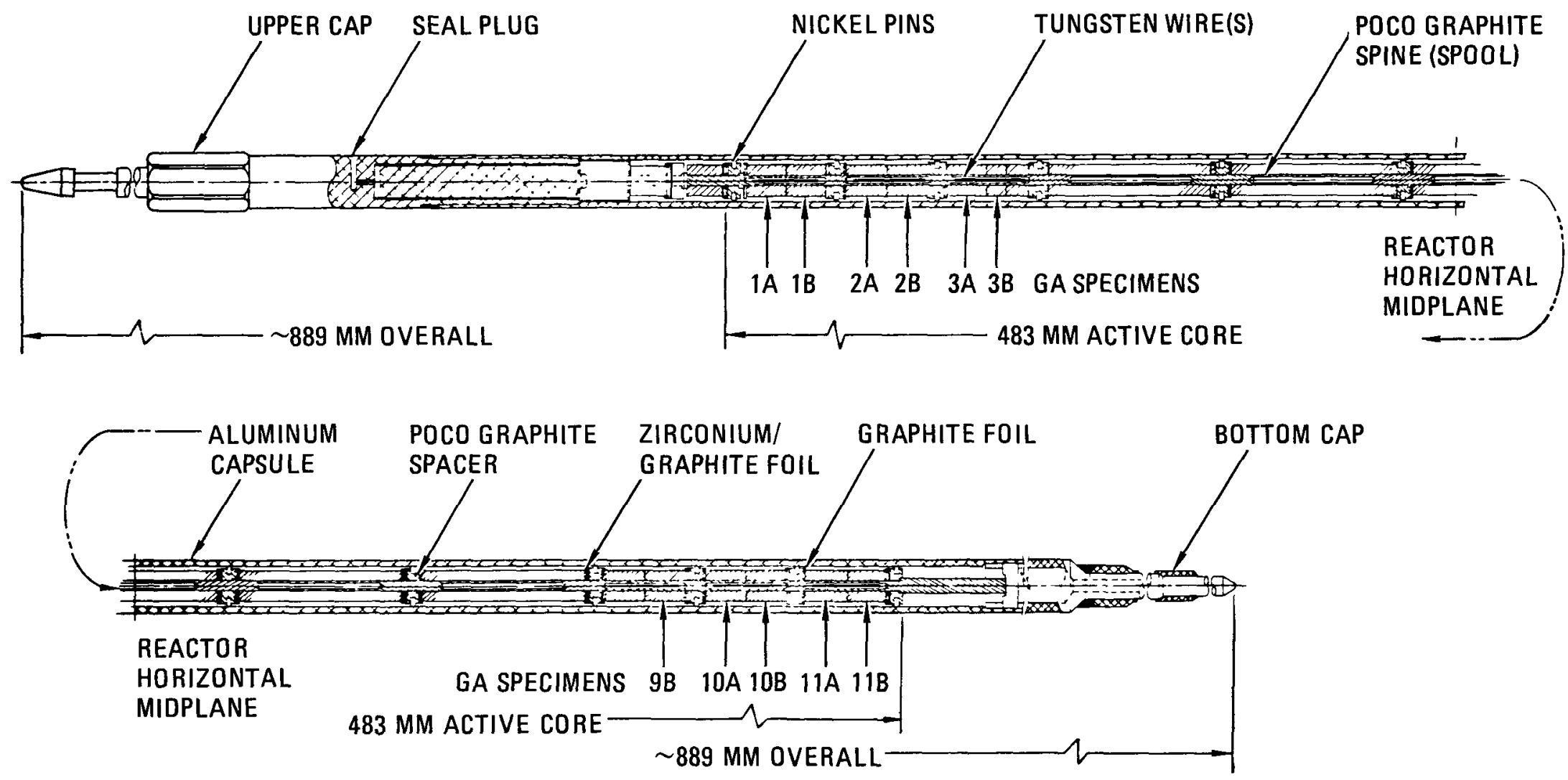

Fig. 2. Schematic of capsules HT-20 through HT-23 
TABLE 1

GRAPHITES IRRADIATED IN CAPSULES HT-20, HT-21, HT-22, AND HT-23

\begin{tabular}{|c|c|c|c|c|c|c|c|c|c|}
\hline \multirow[b]{2}{*}{ Designation } & \multirow[b]{2}{*}{ Type } & \multirow{2}{*}{$\begin{array}{l}\text { Parent Log } \\
\text { Designation }\end{array}$} & \multirow{2}{*}{$\begin{array}{l}\text { Dimensions of } \\
\text { Parent Log }\end{array}$} & \multirow[b]{2}{*}{ Source } & \multicolumn{3}{|c|}{ Raw Materials } & \multirow{2}{*}{$\begin{array}{l}\text { Location/ } \\
\text { Orientation of } \\
\text { Test Specimens } \\
\text { in Parent } \\
\text { Log }\end{array}$} & \multirow{2}{*}{$\begin{array}{l}\text { Mean } \\
\text { Initial } \\
\text { Specimen } \\
\text { Density } \\
\left(\mathrm{Mg} / \mathrm{m}^{3}\right)\end{array}$} \\
\hline & & & & & Filler & Binder & Impregnant & & \\
\hline $\mathrm{H}-451$ & $\begin{array}{l}\text { Extruded } \\
\text { near- } \\
\text { 1sotropic }\end{array}$ & $\begin{array}{l}\log 5651-28 \\
\text { (slab VB) }\end{array}$ & $\begin{array}{l}457 \mathrm{~mm} \text { diameter } x \\
863 \mathrm{~mm} \text { long }\end{array}$ & GLCC & $\begin{array}{l}\text { Near-isotropic } \\
\text { petroleum coke }\end{array}$ & $\begin{array}{l}\text { Coal tar } \\
\text { pitch }\end{array}$ & $\begin{array}{l}\text { Petroleum } \\
\text { pitch }\end{array}$ & $\begin{array}{l}\mathrm{MLC} / \mathrm{axial} \\
\mathrm{MLC} / \mathrm{radial}\end{array}$ & 1.74 \\
\hline $\mathrm{H}-451 \mathrm{~L}$ & $\begin{array}{l}\text { Extruded } \\
\text { near- } \\
\text { isotropic }\end{array}$ & Piece 5651-77 & $\begin{array}{l}41.2 \mathrm{~mm} \times(43.6 \mathrm{~mm} \\
\times 82.5 \mathrm{~mm}(\mathrm{a})\end{array}$ & GLCC & $\begin{array}{l}\text { Near-isotropic } \\
\text { petroleum coke }\end{array}$ & $\begin{array}{l}\text { Coal tar } \\
\text { pitch }\end{array}$ & $\begin{array}{l}\text { Petroleum } \\
\text { pitch }\end{array}$ & $\begin{array}{l}\text { Axial, } \\
\text { radial }\end{array}$ & 1.77 \\
\hline $\mathrm{H}-327$ & $\begin{array}{l}\text { Extruded } \\
\text { aniso- } \\
\text { tropic }\end{array}$ & $\begin{array}{l}\log 4974-3 \\
\text { (slab 15) }\end{array}$ & $\begin{array}{l}457 \mathrm{~mm} \text { diameter } x \\
963 \mathrm{~mm} \text { long }\end{array}$ & GLCC & Needle coke & $\begin{array}{l}\text { Coal tar } \\
\text { pitch }\end{array}$ & $\begin{array}{l}\text { Coal tar } \\
\text { pitch }\end{array}$ & $\begin{array}{l}\text { MLC/axial, } \\
\text { MLC/radial }\end{array}$ & 1.74 \\
\hline $\begin{array}{l}\text { TS-1240 } \\
\text { (low } \\
\text { density) }\end{array}$ & $\begin{array}{l}\text { Extruded } \\
\text { near- } \\
\text { isotropic }\end{array}$ & $\begin{array}{l}\text { Log } 5651-72 \\
\text { (cores } 5651- \\
72-3 \mathrm{~B}-68, \\
\text { axial; } 5651- \\
72-3 \mathrm{~B}-91, \\
\text { radial) }\end{array}$ & $\begin{array}{l}457 \mathrm{~mm} \text { diameter } x \\
863 \mathrm{~mm} \text { long }(\mathrm{b})\end{array}$ & UCC & $\begin{array}{l}\text { Near-isotropic } \\
\text { petroleum coke }\end{array}$ & $\begin{array}{l}\text { Coal tar } \\
\text { pitch }\end{array}$ & $\begin{array}{l}\text { Coal tar } \\
\text { pitch }\end{array}$ & $\begin{array}{l}\text { QLC/axial, } \\
\text { QLC/radial (b) }\end{array}$ & 1.73 \\
\hline $\begin{array}{l}\text { TS- } 1240 \\
\text { (h1gh } \\
\text { density }\end{array}$ & \begin{tabular}{|l|} 
Extruded \\
near- \\
isotropic
\end{tabular} & $\begin{array}{l}\text { Log } 5651-75 \\
\text { (core } 5651-75- \\
-3 B-91, \text { radial) }\end{array}$ & $\begin{array}{l}457 \mathrm{~mm} \text { diameter } \mathrm{x} \\
863 \mathrm{~mm} \text { long }\end{array}$ & UCC & $\begin{array}{l}\text { Near-isotropic } \\
\text { petroleum coke }\end{array}$ & $\begin{array}{l}\text { Coal tar } \\
\text { pitch }\end{array}$ & $\begin{array}{l}\text { Coal tar } \\
\text { pitch }\end{array}$ & $\mathrm{MLC} / \mathrm{radial}$ & 1.81 \\
\hline "x" & $\begin{array}{l}\text { Extruded } \\
\text { near- } \\
\text { isotropic }\end{array}$ & $\begin{array}{l}\text { Extrusion } \\
4194-95\end{array}$ & $\begin{array}{l}15.63 \mathrm{~mm} \text { diameter } \mathrm{x} \\
152 \mathrm{~mm} \text { long }\end{array}$ & $\begin{array}{l}\text { AS/GA/ } \\
\text { ORNL (c) }\end{array}$ & $\begin{array}{l}\text { Near-isotropic } \\
\text { petroleum coke } \\
6361-68(c)\end{array}$ & $\begin{array}{l}\text { Petroleum } \\
\text { pitch } \\
(A-240)(c, d)\end{array}$ & $\begin{array}{l}\text { Petroleum } \\
\text { pitch } \\
(A-240)(c, d)\end{array}$ & Axial & 1.88 \\
\hline
\end{tabular}

(a) Sample was taken near end center (EC) position of a $152.6 \mathrm{~mm}$ diameter by 1220 to $1526 \mathrm{~mm}$ extrusion.

(b) $\log$ was one-half of a 1726-mm-long extrusion. Location of test specimens is relative to parent extrusion.

(c) Fabricated from proprietary AirCo Speer near-1sotropic petroleum coke; extruded and baked at GA; and impregnated, graphitized, and machined at ORNL (see Appendix for description of fabrication).

(d) Ashland Ot1 Company grade A-240 petroleum pitch. 
blocks in LHTGRs. Graphite H-451L is a laboratory version of H-451 developed with the objective of producing a higher degree of isotropy in the macrostructure. Graphite "X" was prepared at General Atomic Company (GA) from a near-isotropic petroleum coke supplied by AirCo Speer Division of the Air Reduction Company (AS) and impregnated at ORNL. The petroleum coke used in graphite " $\mathrm{X}$ " was the same as that used by AS to produce grade s0818, which is also a candidate for fuel element blocks for LHTGRs. Preproduction s0818 was not available when the capsules were inserted. A complete description of the methods used for fabricating graphite " $\mathrm{X}$ " is given in the Appendix.

Specimens of graphites $\mathrm{H}-327, \mathrm{H}-451$, and $\mathrm{TS}-1240$ were taken near the midlength center (MLC) position of full-size (457 mm diameter by $863 \mathrm{~mm}$ long) production logs, both parallel (axial) and perpendicular (radial) to the extrusion direction. The high-density $10 \mathrm{~g}$ of grade TS-1240 was sampled in the radial direction only. The low-density log of grade TS-1240 was onehalf of a $\log$ that was $1726 \mathrm{~mm}$ long during graphitization. This $10 \mathrm{~g}$ was sampled at a quarter-length center (QLC) position in the 1726-mm $10 \mathrm{~g}$, which is equivalent to the MLC position in a 863-mm-long $10 \mathrm{~g}$. Axial and radial specimens of grade $\mathrm{H}-451 \mathrm{~L}$ were taken from a small piece sectioned near the end center (EC) position of a $152.6 \mathrm{~mm}$ diameter by 1220 to $1524 \mathrm{~mm}$ long extruded 1og. Axial samples of graphite " $X$ " were obtained from a $15.63 \mathrm{~mm}$ diameter by $152.6 \mathrm{~mm}$ long extruded rod.

Each of the four capsules contained eleven graphite samples. Sets of samples for each capsule were 1dentical. Specimens were nominally $10.16 \mathrm{~mm}$ diameter by $12.70 \mathrm{~mm}$ or $6.35-\mathrm{mm}-1$ ong cylinders containing an axial 3.22-mmdiameter hole parallel to the longitudinal axis of the specimen. The loading patterns for the capsules are given in Table 2 .

\subsection{PREIRRADIATION DIMENSIONAL MEASUREMENTS}

Preirradiation dimensions of all specimens except those machined at ORNL from graphite " $X$ " were obtained at GA using a Bausch and Lomb DR-25B optical gage. Measurements were made to the nearest $125 \mu \mathrm{m}$. 
TABLE 2
LOADING PATTERN FOR GRAPHITE SAMPLES ${ }^{\text {(a) IN IRRADIATION CAPSULES }}$

HT-20, HT-21, HT-22, AND HT-23

\begin{tabular}{|c|c|c|c|c|c|}
\hline \multirow[b]{2}{*}{ Position ${ }^{(b)}$} & \multirow[b]{2}{*}{ Materia1/Location and Orientation (c) } & \multicolumn{4}{|c|}{ Specimen Numbers } \\
\hline & & HT-20 & HT-21 & $\mathrm{HT}-22$ & $\mathrm{HT}-23$ \\
\hline $1 a$ & Graphite "X"/axial & 49 & 50 & 51 & 52 \\
\hline $1 \mathrm{~b}$ & $\begin{array}{l}\text { Graphite TS }-1240 \text { (10w density)/ } \\
\text { QLC axial }\end{array}$ & 17 & 18 & 19 & 20 \\
\hline $2 a$ & Graphite $\mathrm{H}-327 / \mathrm{MLC}$ radial & 5 & 6 & 7 & 8 \\
\hline $2 b$ & Graphite H-451L/radial & 37 & 38 & 39 & 40 \\
\hline $3 a$ & Graphite H-451/MLC axial & 9 & 10 & 11 & 12 \\
\hline $3 b$ & Graphite "X"/axial (d) & 45 & 46 & 47 & 48 \\
\hline $9 b$ & Graphite H-451L/axial & 29 & 30 & 31 & 32 \\
\hline $10 a$ & Graphite $\mathrm{H}-451 / \mathrm{MLC}$ radial & 13 & 14 & 15 & 16 \\
\hline $10 \mathrm{~b}$ & $\begin{array}{l}\text { Graphite TS }-1240 \text { (low density)/ } \\
\text { QLC radial }\end{array}$ & 21 & 22 & 23 & 24 \\
\hline $11 \mathrm{a}$ & Graphite H-327/MLC axial & 1 & 2 & 3 & 4 \\
\hline $11 \mathrm{~b}$ & $\begin{array}{l}\text { Graphite TS- } 1240 \text { (high density)/ } \\
\text { MLC radial }\end{array}$ & 25 & 16 & 27 & 28 \\
\hline
\end{tabular}

(a) All specimens were $12.70 \mathrm{~mm}$ long unless otherwise specified.

(b) See Fig. 2 .

(c) Location and orientation of specimen in parent extrusion: MLC = midlength center, QLC = quarter-length center.

(d) $6.35 \mathrm{~mm}$ long. 


\section{CAPSULE OPERATION AND EVALUATION}

\subsection{CAPSULE OPERATION}

Capsules HT-20 through HT-23 were irradiated in target positions of the HFIR at ORNL. Table 3 gives an operating history of the four experiments.

Capsule HT-20 was a one-cycle experiment and was inserted in target position E-7 at the beginning of HFIR fuel cycle 108 on June 18, 1974. It was removed at the end of cycle 108 on July 21, 1974, after accumulating 551.52 hours of irradiation at 100-MW reactor power. Capsules HT-21 and HT-22 were inserted in the $\mathrm{E}-2$ and $\mathrm{F}-7$ target positions, respectively, at the beginning of HFIR fuel cycle 109 on July 22, 1974. Capsule HT-22 completed its scheduled four-cycle Irradiation at the end of cycle 112 and was removed from the F-7 position on October 31, 1974, after accumulating 2192.56 hours of irradiation at $100-\mathrm{MW}$ reactor power. Capsule HT-21, a six-cycle experiment, was removed from target position E-2 at the end of cycle 114 on December 18, 1974, after accumulating 3292.96 hours of irradiation at 100-MW reactor power. Capsule HT-23 was inserted into target position $\mathrm{A}-3$ at the beginning of HFIR fuel cycle 111 on September 12, 1974 and was removed at the end of cycle 112 on October 31, 1974. During the two cycles it accumulated 1096.08 hours of irradiation at 100-MW reactor power. The operation of a11 capsules was stable throughout their irradiation periods.

\subsection{IRRADIATION CONDITIONS}

The fast neutron fluences are reported in Table 4. The data are reported in an HTGR neutron spectrum. It is recognized that fast neutrons in the 50 to $180 \mathrm{KeV}$ energy range also contribute Irradiation damage (Ref. 2). 
TABLE 3

REACTOR POWER HISTORY FOR CAPSULES HT-20 THROUGH HT-23

\begin{tabular}{|c|c|c|c|c|c|c|c|c|}
\hline \multirow[b]{3}{*}{ Capsule } & \multirow[b]{3}{*}{ Facility } & \multirow{3}{*}{$\begin{array}{l}\text { HFIR } \\
\text { Fue1 } \\
\text { Cycle }\end{array}$} & \multirow{2}{*}{\multicolumn{2}{|c|}{ Begin }} & \multirow{2}{*}{\multicolumn{2}{|c|}{ End }} & \multicolumn{2}{|c|}{$\begin{array}{c}\text { Irradiation Time } \\
\text { (hours) }\end{array}$} \\
\hline & & & & & & & & \\
\hline & & & Time & Date & Time & Date & Cycle & Accumulated \\
\hline $\mathrm{HT}-20$ & $\mathrm{~F}-7$ & 108 & 1406 & $6 / 28 / 74$ & 1340 & $7 / 21 / 74$ & 551.52 & 551.52 \\
\hline HT- 21 & $\begin{array}{l}E-2 \\
E-2 \\
E-2 \\
E-2 \\
E-2 \\
E-2\end{array}$ & $\begin{array}{l}109 \\
110 \\
111 \\
112 \\
113 \\
114\end{array}$ & $\begin{array}{l}1842 \\
1707 \\
1030 \\
0525 \\
0318 \\
1332\end{array}$ & $\begin{array}{l}7 / 22 / 74 \\
8 / 15 / 74 \\
9 / 12 / 74 \\
10 / 6 / 74 \\
11 / 1 / 74 \\
11 / 25 / 74\end{array}$ & $\begin{array}{l}0400 \\
2012 \\
0736 \\
0218 \\
1028 \\
0400\end{array}$ & $\begin{array}{l}8 / 15 / 74 \\
9 / 9 / 74 \\
10 / 5 / 74 \\
10 / 31 / 74 \\
11 / 24 / 74 \\
12 / 18 / 74\end{array}$ & $\begin{array}{l}546.88 \\
549.60 \\
548.88 \\
547.20 \\
558.72 \\
541.68\end{array}$ & $\begin{array}{r}546.88 \\
1096.48 \\
1645.36 \\
2192.56 \\
2751.28 \\
3292.96\end{array}$ \\
\hline HT- 22 & $\begin{array}{l}F-7 \\
F-7 \\
F-7 \\
F-7\end{array}$ & $\begin{array}{l}109 \\
110 \\
111 \\
112\end{array}$ & $\begin{array}{l}1842 \\
1707 \\
1030 \\
0525\end{array}$ & $\begin{array}{l}7 / 22 / 74 \\
8 / 15 / 74 \\
9 / 12 / 74 \\
10 / 6 / 74\end{array}$ & $\begin{array}{l}0400 \\
2012 \\
0736 \\
0218\end{array}$ & $\begin{array}{l}8 / 15 / 74 \\
9 / 9 / 74 \\
10 / 5 / 74 \\
10 / 31 / 74\end{array}$ & $\begin{array}{l}546.88 \\
549.60 \\
548.88 \\
547.20\end{array}$ & $\begin{array}{r}546.88 \\
1096.48 \\
1645.36 \\
2192.56\end{array}$ \\
\hline HT -23 & $\begin{array}{l}A-3 \\
A-3\end{array}$ & $\begin{array}{l}111 \\
112\end{array}$ & $\begin{array}{l}1030 \\
0525\end{array}$ & $\begin{array}{l}9 / 12 / 74 \\
10 / 6 / 74\end{array}$ & $\begin{array}{l}0736 \\
0218\end{array}$ & $\begin{array}{l}10 / 5 / 74 \\
10 / 31 / 74\end{array}$ & $\begin{array}{l}548.88 \\
547.20\end{array}$ & $\begin{array}{r}548.88 \\
1096.08\end{array}$ \\
\hline
\end{tabular}


TABLE 4

CALCULATED FAST FLUENCES FOR CAPSULES HT-20 THROUGH HT-23

\begin{tabular}{|c|c|c|c|c|c|}
\hline \multirow{2}{*}{$\begin{array}{l}\text { Specimen } \\
\text { Position }\end{array}$} & \multirow{2}{*}{$\begin{array}{l}\text { Distance From } \\
\text { Reactor Horizontal } \\
\text { Midplane to } \\
\text { Specimen } \\
(\mathrm{mm})\end{array}$} & \multicolumn{4}{|c|}{$\begin{array}{c}\text { Fast F1uence } \times 10^{-25}\left(\mathrm{n} / \mathrm{m}^{2}\right) \\
(\mathrm{E}>29 \mathrm{fJ})_{\mathrm{HTGR}}\end{array}$} \\
\hline & & $\mathrm{HT}-20$ & $\mathrm{HT}-21$ & HT -22 & $\mathrm{HT}-23$ \\
\hline $\begin{array}{l}1 a, 1 b \\
11 a, 11 b\end{array}$ & 222.2 & 1.215 & 7.253 & 4.831 & 2.415 \\
\hline $\begin{array}{l}2 a, 2 b, \\
10 a, 10 b\end{array}$ & 190.5 & 1.509 & 9.007 & 5.998 & 2.999 \\
\hline $\begin{array}{l}3 a, 3 b, \\
9 b\end{array}$ & 158.8 & 1.767 & 10.548 & 7.025 & 3.512 \\
\hline
\end{tabular}


The flux spectrum in the HFIR differs somewhat from the design flux spectrum in the LHTGR in that a unit fast flux with the HFIR spectrum is more damaging than a unit fast flux with the LHTGR spectrum. An equivalent fluence in an HTGR environment ( $(2>29 \mathrm{fJ})_{\mathrm{HTGR}}$ is equal to approximately 0.90 of that in the HFIR environment $(E>29 \mathrm{fJ})_{\text {HTGR }}$ (Ref. 3).

Capsules HT-20 through HT-23 were designed to operate at a nominal specimen centerline temperature of $1223 \mathrm{~K}$. The capsules were uninstrumented and had no provisions for maintaining specimen design temperatures during irradiation. Therefore, the nominal temperature of $1223 \mathrm{~K}$ is at best an estimate and should not be construed as a measured temperature. Heating of the specimens was achieved by ganma-ray attenuation in tungsten wires, which were located in hollow graphite spines passing through the axial center hole of each specimen stack (two or three specimens). A specific (calculated) and varying amount of tungsten wire was used for each specimen stack along the capsule length to compensate for axial variations in heat generation due to a nonuniform neutron flux profile and also to provide the required irradiation temperature. Calculated specimen temperatures for all capsules based on minimum amounts of tungsten used for each position were 1214 to $1238 \mathrm{~K}$. 


\section{POSTIRRADIATION EXAMINATION RESULTS}

Capsules HT-20 through HT-23 were disassembled in the Low Radiation Level Examination Laboratory (clean hot cells) at ORNL. After the specimens were removed from each capsule, they were individually loaded into small plastic vials and transferred in a lead-shielded container to the Metals and Ceramics Division Laboratory for postirradiation dimensional measurements. After measurement, the specimens from each capsule were resealed in individual plastic vials. The vials were placed in a lead insert and sealed in an isotope can and shipped to GA where additional postirradiation dimensional measurements were made.

\subsection{CAPSULE DISASSEMBLY AND SPECIMEN REMOVAL}

Each capsule was disassembled by removing the outer aluminum containment tube and exposing the graphite specimens, spacers, and alignment spines. The capsule parts and specimens from all four capsules were essentially free of sooty material, confirming the effectiveness of the interspacer zirconium foils used as getters in the experiments. The graphite specimens were easily removed from the graphite spines in all four capsules with the exception of three specimens in HT-21 and two specimens in HT-22, where the graphite specimens were clamped to the spines and had to be forcibly removed. As a result, the three specimens in capsule HT-21 (positions $2 b$, $3 a$, and $9 b$ ) were chipped during removal and the two specimens in capsule HT-22 (positions $2 \mathrm{~b}$ and $9 \mathrm{~b}$ ) were broken or cracked. These specimens were discarded.

\subsection{SPECIMEN DIMENSIONAL MEASUREMENTS}

Postirradiation dimensional measurements were initially made at ORNL on all specimens using a ratchet micrometer or "supermike." Measurements were made to the nearest $250 \mu \mathrm{m}$. 
The dimensional change of each specimen was calculated from the length of the specimen taken prior to irradiation $\left(l_{0}\right)$ and the length taken after irradiation $(l)$. The irradiation-induced dimensional change for each specimen was calculated from the equation:

$$
\% \text { change }=100\left[\ln \left(\ell / \ell_{0}\right)\right]
$$

Each graphite specimen was assigned an average calculated irradiation temperature of $1231 \mathrm{~K}$ and a mean fast neutron fluence based on the specimen location in each capsule.

The dimensional changes for all specimens except those of graphite " $\mathrm{X}$ " were calculated from preirradiation and postirradiation measurements obtained at GA. The dimensional changes of graphite " $X$ " specim .s were obtained from preirradiation and postirradiation measurements taken at ORNL. Although both ORNL measurements were made using a different measurement device than that used at GA ("supermike" versus calibrated dial indicator), measurements made on standards showed negligible differences between the two methods.

The dimensional changes of the specimens are presented in Table 5. The dimensional changes of the five graphites are plotted as a function of fluence in Figs. 3 through 7, which include hand-drawn dimensional change curves using the data presented in Table 5 .

In the radial direction, grades $\mathrm{H}-327$ and $\mathrm{H}-451$ exhibited initial contraction followed by expansion (turnaround) at an HTGR fluence of about $5.5 \times 10^{25} \mathrm{n} / \mathrm{m}^{2}$, whereas grade TS-1240 exhibited no dimensional change except for a slight expansion at $8 \times 10^{25} \mathrm{n} / \mathrm{m}^{2}$. No difference was observed between the dimensional changes for the low- and high-density TS-1240 logs. Grade H-327 exhibited a maximum radial shrinkage of $0.6 \%$, and net expansion began at about $7.5 \times 10^{25} \mathrm{n} / \mathrm{m}^{2}$. $\mathrm{H}-451$ exhibited a maximum radial contraction of $0.8 \%$ and sti11 showed a net shrinkage at fluences greater than $8 \times 10^{25} \mathrm{n} / \mathrm{m}^{2}$. Graphite "X" was not tested in the radial direction. 
TABLE 5

DIMENSIONAL CHANGES OF GRAPHITES IRRADIATED IN CAPSULES HT-20, HT-21, HT-22, AND HT- 23

\begin{tabular}{|c|c|c|c|c|c|}
\hline $\begin{array}{l}\text { Specimen } \\
\text { Number }\end{array}$ & Graphite & $\begin{array}{l}\text { Location } \\
\text { (Orientation) } \\
\text { In Parent } \\
\text { Extrusion }(a)\end{array}$ & $\begin{array}{l}\text { Location } \\
\text { in } \\
\text { Capsule }\end{array}$ & $\begin{array}{l}\text { Fast Fluence } \\
\times 10^{-25}\left(\mathrm{n} / \mathrm{m}^{2}\right) \\
(\mathrm{E}>29 \mathrm{fJ})_{\mathrm{HTGR}}\end{array}$ & $\begin{array}{l}\text { Irradiation- } \\
\text { Induced } \\
\text { Dimenslonal } \\
\text { Change, } \\
\text { ln }(\ell / \ell) \\
(\%)\end{array}$ \\
\hline \multicolumn{6}{|c|}{ HT -20} \\
\hline $\begin{array}{r}49 \\
17 \\
5 \\
37 \\
9 \\
45 \\
29 \\
13 \\
21 \\
1 \\
25\end{array}$ & $\begin{array}{l}\text { "X" } \\
T S-1240(c) \\
H-327 \\
H-451 L \\
H-451 \\
" X " \\
H-451 L \\
H-451 \\
T S-1240(c) \\
H-327 \\
T S-1240 \text { (d) }\end{array}$ & $\begin{array}{l}\text { (Axial) } \\
\text { QLC (axial) } \\
\text { MLC (radial) } \\
\text { (Axial) } \\
\text { MLC (axial) } \\
\text { (Axial) } \\
\text { (Axial) } \\
\text { MLC (radial) } \\
\text { QLC (radial) } \\
\text { MLC (axial) } \\
\text { MLC (radial) }\end{array}$ & $\begin{array}{r}1 \mathrm{a} \\
1 \mathrm{~b} \\
2 \mathrm{a} \\
2 \mathrm{~b} \\
3 \mathrm{a} \\
3 \mathrm{~b} \\
9 \mathrm{~b} \\
10 \mathrm{a} \\
10 \mathrm{~b} \\
11 \mathrm{a} \\
11 \mathrm{~b} \\
\end{array}$ & $\begin{array}{l}1.094 \\
1.094 \\
1.358 \\
1.358 \\
1.589 \\
1.589 \\
1.589 \\
1.358 \\
1.358 \\
1.094 \\
1.094 \\
\end{array}$ & $\begin{array}{l}-0.104 \\
-0.140 \\
-0.200 \\
-0.281 \\
-0.381 \\
-0.725 \\
-0.527 \\
-0.248 \\
-0.184 \\
-0.186 \\
-0.050\end{array}$ \\
\hline \multicolumn{6}{|c|}{ нТ- 23} \\
\hline $\begin{array}{r}52 \\
20 \\
8 \\
40 \\
12 \\
48 \\
32 \\
16 \\
24 \\
4 \\
28\end{array}$ & $\begin{array}{l}\text { "X" } \\
T S-1240 \text { (c) } \\
H-327 \\
H-451 L \\
H-451 \\
\text { "X" } \\
H-451 L \\
H-451 \\
\text { TS-1240 (c) } \\
H-327 \\
\text { TS- } 1240 \text { (d) }\end{array}$ & $\begin{array}{l}\text { (Axial) } \\
\text { QLC (axial) } \\
\text { MLC (radial) } \\
\text { (Radial) } \\
\text { MLC (axial) } \\
\text { (Axial) } \\
\text { (Axial) } \\
\text { MLC (radial) } \\
\text { QLC (radial) } \\
\text { MLC (axial) } \\
\text { MLC (radial) }\end{array}$ & $\begin{array}{r}1 \mathrm{a} \\
1 \mathrm{~b} \\
2 \mathrm{a} \\
2 \mathrm{~b} \\
3 \mathrm{a} \\
3 \mathrm{~b} \\
9 \mathrm{~b} \\
10 \mathrm{a} \\
10 \mathrm{~b} \\
11 \mathrm{a} \\
11 \mathrm{~b}\end{array}$ & $\begin{array}{l}2.175 \\
2.175 \\
2.700 \\
2.700 \\
3.165 \\
3.165 \\
3.165 \\
2.700 \\
2.700 \\
2.175 \\
2.175\end{array}$ & $\begin{array}{l}-0.272 \\
-0.140 \\
-0.438 \\
-0.918 \\
-1.184 \\
-1.356 \\
-1.680 \\
-0.401 \\
+0.064 \\
-0.575 \\
+0.132\end{array}$ \\
\hline \multicolumn{6}{|c|}{ HT- 22} \\
\hline $\begin{array}{l}51 \\
19 \\
7 \\
39 \\
11 \\
47 \\
31(\mathrm{e}) \\
15 \\
23 \\
3 \\
27\end{array}$ & $\begin{array}{l}\text { "X" } \\
\text { IS-1240 (c) } \\
H-327 \\
H-451 L \\
H-451 \\
\text { "X" } \\
H-451 L \\
H-451 \\
\text { TS-1240 (c) } \\
H-327 \\
\text { TS- } 1240 \text { (d) }\end{array}$ & $\begin{array}{l}\text { (Axial) } \\
\text { QLC (axial) } \\
\text { MLC (radial) } \\
\text { (Radial) } \\
\text { MLC (axial) } \\
\text { (Axial) } \\
\text { (Axial) } \\
\text { MLC (radial) } \\
\text { QLC (radia1) } \\
\text { MLC (axial) } \\
\text { MLC (radial) }\end{array}$ & $\begin{array}{r}1 \mathrm{a} \\
1 \mathrm{~b} \\
2 \mathrm{a} \\
2 \mathrm{~b} \\
3 \mathrm{a} \\
3 \mathrm{~b} \\
9 \mathrm{~b} \\
10 \mathrm{a} \\
10 \mathrm{~b} \\
11 \mathrm{a} \\
11 \mathrm{~b}\end{array}$ & $\begin{array}{l}4.350 \\
4.350 \\
5.400 \\
5.400 \\
6.320 \\
6.320 \\
6.320 \\
5.400 \\
5.400 \\
4.350 \\
4.350\end{array}$ & $\begin{array}{c}-1.247 \\
-0.527 \\
-0.597 \\
(\mathrm{e}) \\
-2.609 \\
-2.263 \\
(\mathrm{e}) \\
-0.768 \\
+0.024 \\
-1.596 \\
+0.062\end{array}$ \\
\hline \multicolumn{6}{|c|}{ HT- 21} \\
\hline $\begin{array}{l}50 \\
18 \\
6 \\
38(e) \\
10(e) \\
46 \\
30(e) \\
14 \\
22 \\
2 \\
26\end{array}$ & $\begin{array}{l}\text { "X" } \\
T S-1240 \text { (c) } \\
H-327 \\
H-451 L \\
H-451 \\
\text { "X" } \\
H-451 L \\
H-451 \\
T S-1240 \text { (c) } \\
H-327 \\
T S-1240 \text { (d) }\end{array}$ & $\begin{array}{l}\text { (Axial) } \\
\text { QLC (radial) } \\
\text { MLC (radial) } \\
\text { (Radial) } \\
\text { MLC (axial) } \\
\text { (Axial) } \\
\text { (Axial) } \\
\text { MLC (radial) } \\
\text { QLC (radial) } \\
\text { MLC (axial) } \\
\text { MLC (radial) }\end{array}$ & $\begin{array}{r}1 \mathrm{a} \\
1 \mathrm{~b} \\
2 \mathrm{a} \\
2 \mathrm{~b} \\
3 \mathrm{a} \\
3 \mathrm{~b} \\
9 \mathrm{~b} \\
10 \mathrm{a} \\
10 \mathrm{~b} \\
11 \mathrm{a} \\
11 \mathrm{~b}\end{array}$ & $\begin{array}{l}6.530 \\
6.530 \\
8.110 \\
8.110 \\
9.490 \\
9.490 \\
9.490 \\
8.110 \\
8.110 \\
6.530 \\
6.530\end{array}$ & $\begin{array}{c}-2.119 \\
-0.988 \\
+0.353 \\
(e) \\
(e) \\
-1.815 \\
(e) \\
-0.290 \\
+0.176 \\
-3.265 \\
0.000\end{array}$ \\
\hline
\end{tabular}

(a) ${ }_{M L C}=$ midlength center, $Q L C=$ quarter-1ength center.

(b) See Fig. 2 .

(c) Low-density log.

(d) High-density log.

(e) Specimens stuck to spines and were discarded. 


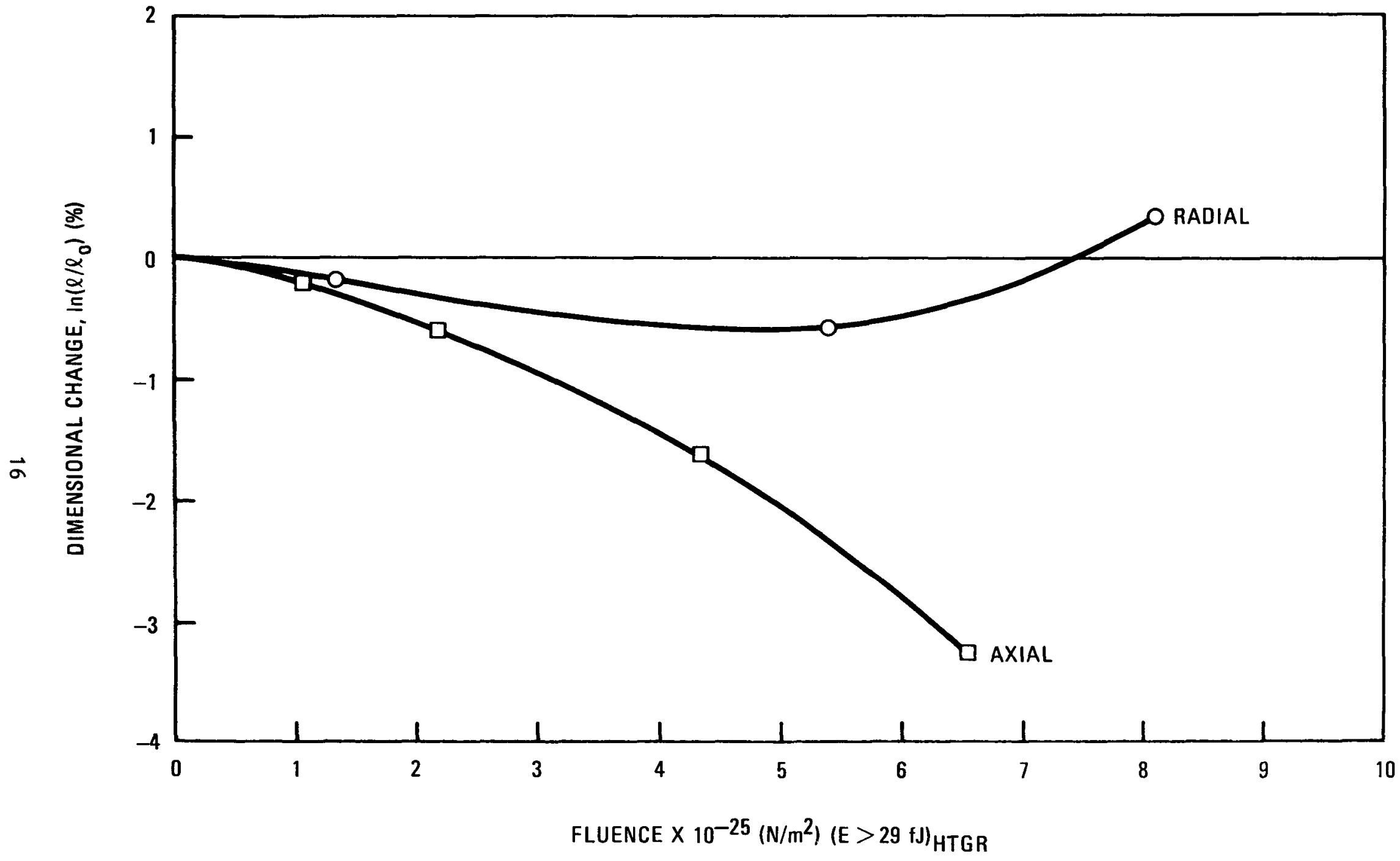

Fig. 3. Dimensional changes of H-327 graphite as a function of fast neutron fluence at an irradlation temperature of 1214 to $1238 \mathrm{~K}$ 


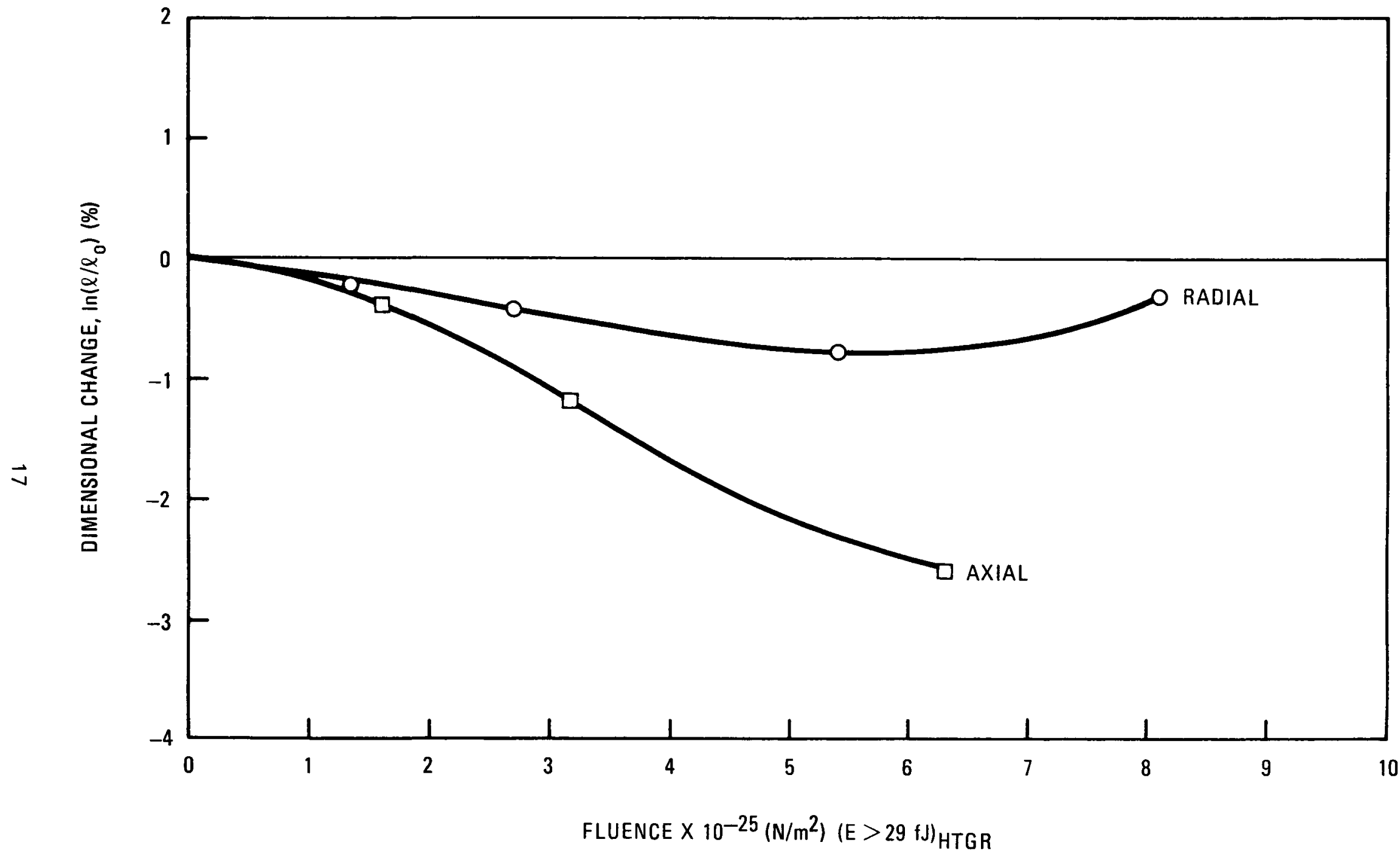

Fig. 4. Dimensional changes of $\mathrm{H}-451$ graphite as a function of fast neutron fluence at an irradiation temperature of 1214 to $1238 \mathrm{~K}$ 


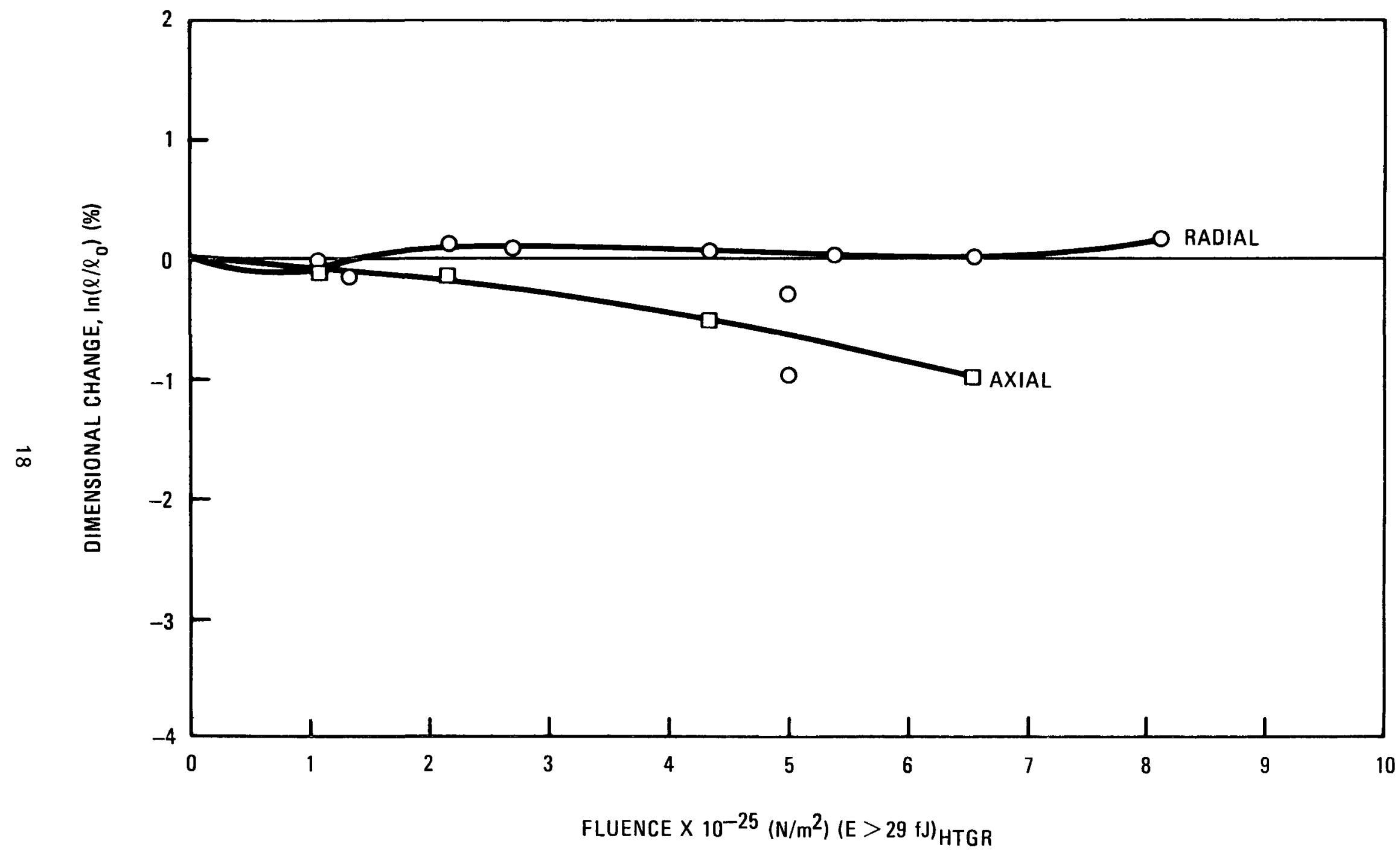

Fig. 5. Dimensional changes of TS-1240 graphite as a function of fast neutron fluence at an irradiation temperature of 1214 to $1238 \mathrm{~K}$ 


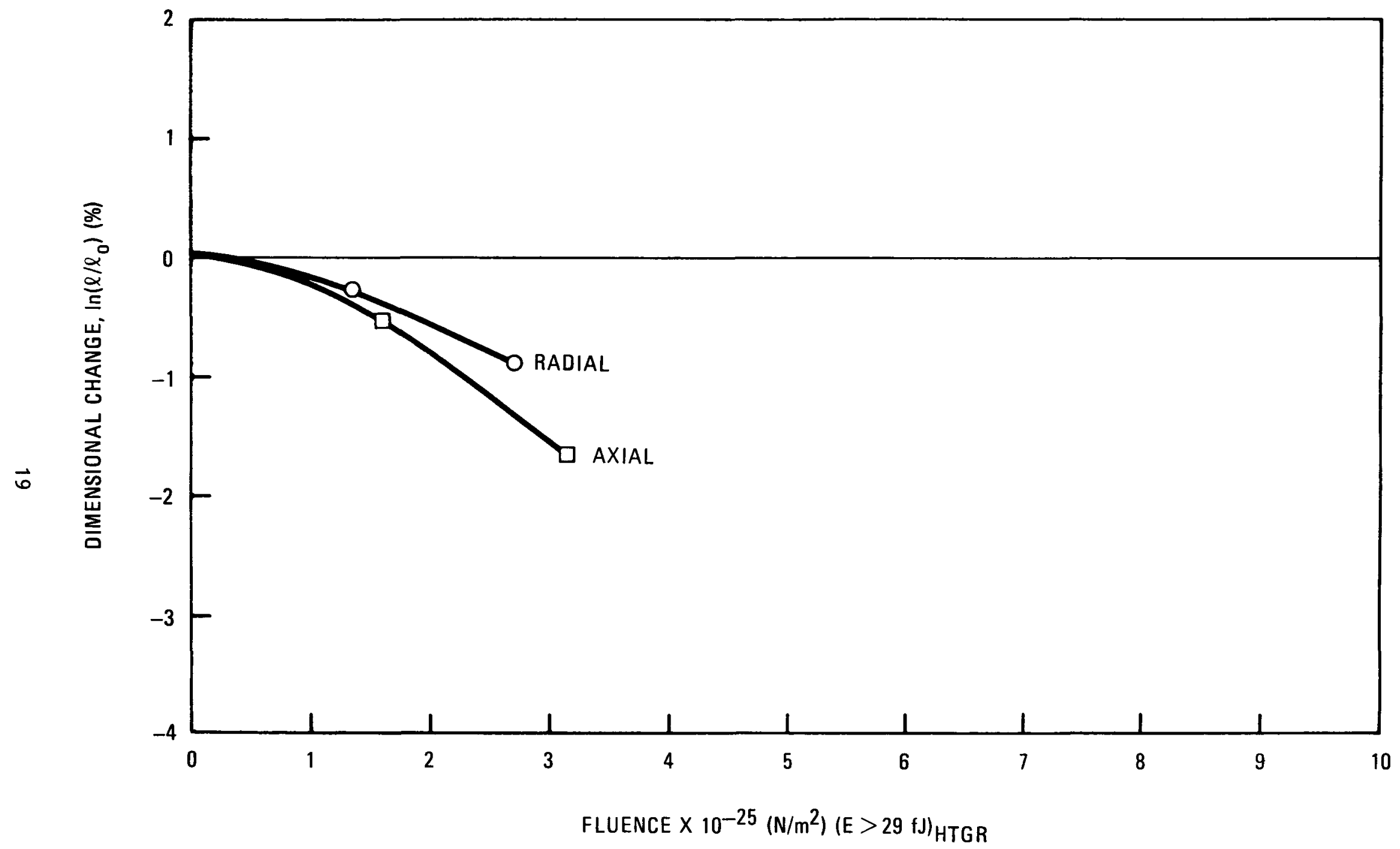

Fig. 6. Dimensional changes of H-451L graphite as a function of fast neutron fluence at an irradiation temperature of 1214 to $1238 \mathrm{~K}$ 


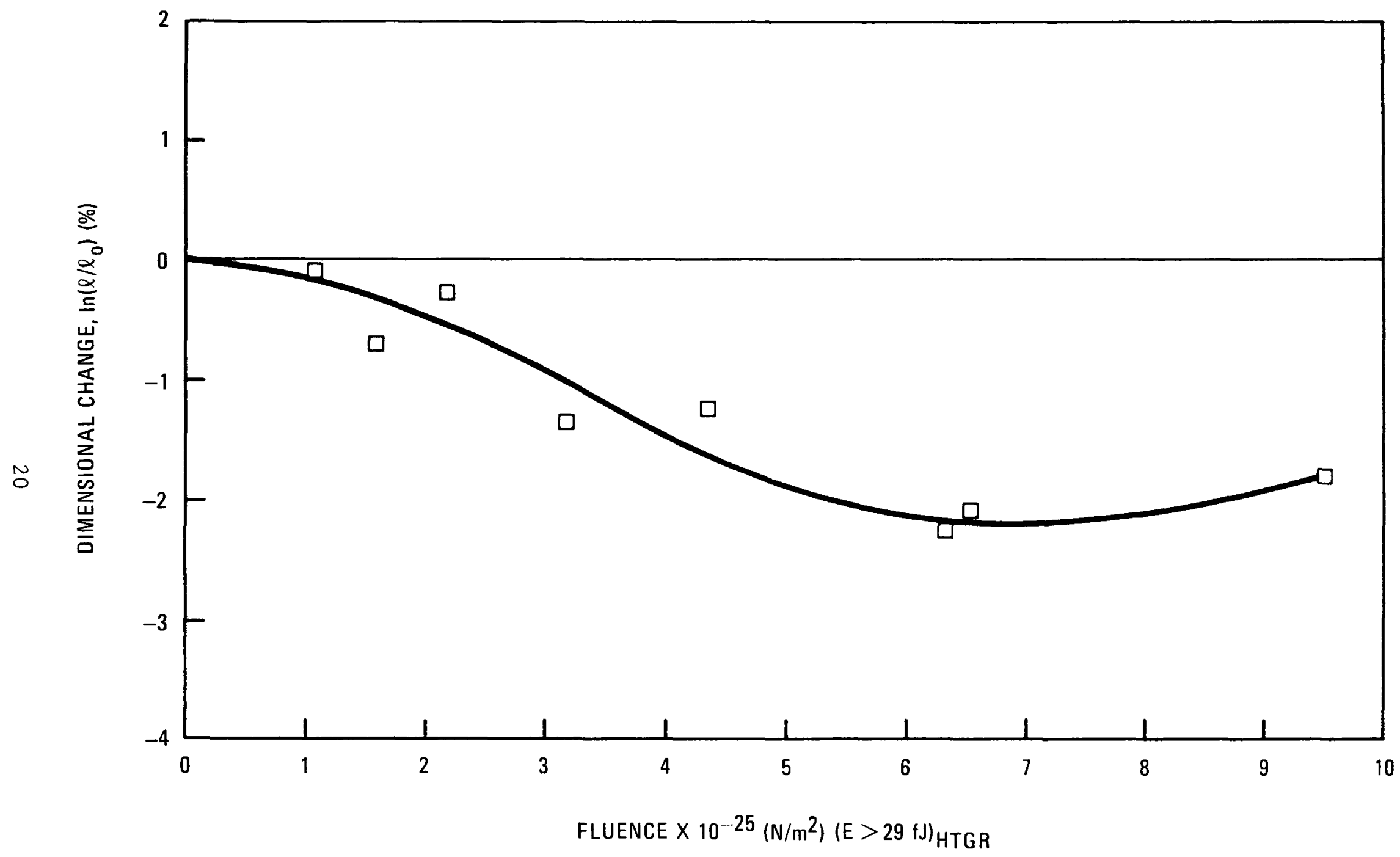

Fig. 7. Axial dimensional change of graphite " $\mathrm{X}$ " as a function of fast neutron fluence at an irradiation temperature of 1214 to $1238 \mathrm{~K}$ 
In the axial direction, all graphites exhibited net contractions at the maximum fluences to which they were tested. Grade H-327 shrank $3.25 \%$ and showed no indication of turnaround at the maximum test fluence of $6.5 \times 10^{25} \mathrm{n} / \mathrm{m}^{2}$. Grade TS -1240 contracted $1.0 \%$ at its maximum test fluence of $6.5 \times 10^{25} \mathrm{n} / \mathrm{m}^{2}$. Graphite " $\mathrm{X}$ " contracted initially to a maximum of $2.25 \%$ and turnaround commenced at $6.5 \times 10^{25} \mathrm{n} / \mathrm{m}^{2}$. Grade $\mathrm{H}-451 \mathrm{~L}$ contracted $1.75 \%$ at a test fluence of $3 \times 10^{25} \mathrm{n} / \mathrm{m}^{2}$. 


\section{CONCLUSIONS}

Five fuel element graphite candidates were irradiated at approximately $1226 \mathrm{~K}$ to fluences of $1 \times 10^{25}$ to $9.5 \times 10^{25} \mathrm{n} / \mathrm{m}^{2}$ (E $>29 \mathrm{fJ}$ ) $\mathrm{HTGR}$ to provide a direct comparison of their dimensional stability at a single temperature. H-327 graphite exhibited the greatest axial shrinkage and TS-1240 the least. Graphite " $X$ " behaved similarly to grade $\mathrm{H}-451$ in the axial direction. Grade TS-1240 exhibited no radial dimensional change up to $6.5 \times 10^{25} \mathrm{n} / \mathrm{m}^{2}$ and slight expansion at $8 \times 10^{25} \mathrm{n} / \mathrm{m}^{2}$. 


\section{ACKNOWLEDGMENTS}

The author would like to acknowledge the contributions of L. Bailey, C. H. Richards, Jr., and J. R. Whaley of GA and J. M. Robbins and C. R. Kennedy of ORNL for specimen fabrication, capsule disassembly, and preirradiation and postirradiation dimensional measurements. 


\section{REFERENCES}

1. Price, R. J., and L. A. Beavan, "Final Report on Graphite Irradiation Test OG-2," ERDA Report GA-A13556, General Atomic Company, December 15, 1975, Sections 5.1 and 5.2 .

2. Engle, G. B., and W. P. Eather1y, "Review of High-Temperature Graphite Irradiation Behavior," High Temperature - High Pressure 4, 119 (1972).

3. Kerr, H. T., E. J. Allen, and D. L. Reed, "Lattice Displacement Calculations and Comparisons for Different Irradiation Facilities," ERDA Report TM-5269, Oak Ridge National Laboratory, March 1976, p. 8. 
APPENDIX

FABRICATION OF GRAPHITE "X"

The material designated graphite " $X$ " was prepared jointly by GA and ORNL from a proprietary near-isotropic petroleum coke (GA 5361-68, AS 6969E) furnished by the AirCo Speer Division of the Air Reduction Company.

Graphite "X" was formulated, extruded (GA coke evaluation run 4194-95), and baked at GA in accordance with a standard electrode fabrication process. Ashland Oil Company type A-240 petroleum pitch was used as the binder. The green extruded material was $15.63 \mathrm{~mm}$ in diameter by $152 \mathrm{~mm}$ 1ong. The green density of the extruded rod was $1.62 \mathrm{Mg} / \mathrm{m}^{3}$ and the baked density was 1.75 $\mathrm{Mg} / \mathrm{m}^{3}$.

Impregnation and graphitization of graphite " $\mathrm{X}$ " were conducted at ORNL as follows:

1. Impregnation. The baked specimen was placed in a wide-mouthed container and covered with dry granulated Ashland A-240 petroleum pitch. The container was placed in an autoclave, evacuated to about $10 \mu \mathrm{m}$, heated to $423 \mathrm{~K}$ at $100 \mathrm{~K} /$ hour, and held at this temperature for 5.5 hours. The autoclave was pressurized to 7 to $10 \mathrm{MPa}$ while increasing the temperature to $473 \mathrm{~K}$. After 19 hours at $473 \mathrm{~K}$, the temperature and gas pressure were increased to $673 \mathrm{~K}$ and 14 to 17 $\mathrm{MPa}$, respectively. These conditions were maintained for 46 hours after which the power was turned off, the container was allowed to furnace-cool under pressure, and the extrusion was removed from the autoclave.

2. Bake. The extrusion was heated in argon as follows: (1) room temperature to $573 \mathrm{~K}$ at $20 \mathrm{~K} /$ hour, (2) 573 to $923 \mathrm{~K}$ at $10 \mathrm{~K} / \mathrm{hour}$, and (3) 923 to $1173 \mathrm{~K}$ at $20 \mathrm{~K} /$ hour. The extrusion was then furnace-cooled. The baked density was $1.73 \mathrm{Mg} / \mathrm{m}^{3}$. 
3. Reimpregnation and rebake. The extrusion was reimpregnated and rebaked in accordance with the procedures described in (1) and (2) above. The final baked density of the specimen was $1.80 \mathrm{Mg} / \mathrm{m}^{3}$.

4. Graphitization. Graphitization was carried out in argon as follows: (1) heat from room temperature to $2273 \mathrm{~K}$ in 12 hours at a linear rate, (2) heat from 2273 to $3073 \mathrm{~K}$ in 12 hours, (3) maintain at $3073 \mathrm{~K}$ for 1 hour, and (4) furnace-cool. The graphitized density was $1.89 \mathrm{Mg} / \mathrm{m}^{3}$. 